\title{
A Survey on the Swimming Abilities among Secondary School Students in Hong Kong 香港中學生的游泳能力
}

\author{
Lobo LOUIE Ka Chun WONG Bik C. CHOW \\ Department of Physical Education, \\ Hong Kong Baptist University, HONG KONG
}

雷雄德 黃家俊周珵珠

香港浸會大學體育學系

\begin{abstract}
The purpose of this study is to understand the swimming abilities among the secondary school students in Hong Kong. A total of 1,752 subjects replied to the survey and it revealed that $46.7 \%$ of the secondary students were unable to swim. There are significant differences between observed and expected frequencies for the secondary students who were able and unable to swim in gender and family income but no significant difference were found among school levels. Parental encouragement was the major reason for the secondary students participating in swimming activity. This finding provided the database for the school administrators and health care professionals to better understand the current situation about the swimming abilities among the secondary school students in Hong Kong.
\end{abstract}

\section{摘 要}

本調查旨在探討本港中學生的游泳能力, 採用問卷形式收集了 1752 名中學生, 結果顯示有 $46.7 \%$ 不懂游泳, 盼望學校及教育 部門加以關注。

\section{Introduction}

Swimming is an exercise that is suitable to nearly everyone. It is not only a tool for recreation or therapy, but also a survival skill. Swimming is beneficial for kids with health problems ranging from arthritis to asthma. Overweight children will find that swimming is an easier form of exercise than others such as running or playing basketball. The movement in the water makes exercising easier and more fun for overweight children.

Although swimming is an excellent form of exercise, however, like many activities, swimming in a pool or the beach sometimes has its downside. According to Center for Disease Control and Prevention (2014), about ten people die every day from unintentional drowning. Of these, two are children 14 or younger. In general, 6.8 per 100,000 persons annually is the global mortality rate from drowning (Onyekwelu, 2009). Drowning in children is a major public health burden and a leading cause of mortality in young children (Brenner, 2009). In Hong Kong, the Leisure and Cultural Services Department (2009) reported that the mortality rate from drowning is 1 per 10,573 persons at the beach and 1 per 11,840 persons at the swimming pool. In Hong Kong, the Leisure and Cultural Services Department provided the statistics of drowning, near drowning, rescue cases, and give-a-hand 
cases both in swimming pool and beach annually. For the past three years, nine people were dead due to drowning either in the swimming pool or the beaches. Table 1 shows the numbers of rescue, drowning, give-a-hand, and accident cases at public swimming pools and bathing beaches in 2012 (Leisure \& Cultural Services Department, 2012).

Table 1. Numbers of Rescue, Drowning, Give-a-hand, Accident Cases at Public Swimming Pools and Bathing Beaches in 2012.

\begin{tabular}{|l|c|c|}
\hline & $\begin{array}{c}\text { Public } \\
\text { Swimming Pools }\end{array}$ & Bathing Beaches \\
\hline Rescue case & 70 & 2 \\
\hline Drowning case & 2 & 892 \\
\hline Give-a-hand case & 1,350 & 93 \\
\hline Accident case & 311 & 2 \\
\hline
\end{tabular}

In fact, the accidents of drowning and near-drowning rate happened outside the beach and swimming pool were not reported. However, it was generally accepted that drowning was a leading cause of injury-related death among children and the major public health burden (Onyekwelu, 2008; Brenner, 2003; O’Flaherty \& Pirie, 1997).

The Center for Disease Control and Prevention indicates that learning to swim is the best way to protect from drowning. Formal swimming lessons can reduce the risk of drowning by as much as $88 \%$ among young children aged 1 to 4 years, who are at greatest risk of drowning. Brenner (2003) suggested that increased swimming ability decreased the risk of submersion injury and that this effect was greater for older children. However, there was only handful data concerning the children's swimming abilities in Hong Kong. Thus, the purpose of this study was to understand the swimming abilities among the secondary school students. The present survey also focused on collecting a variety of information related to learning to swim, such as obstacles and perceived difficulties about learning to swim. Hopefully, such data would provide useful information for the local school administrators, parents as well as the public to better understand the current situation on the swimming abilities among the secondary school students.

\section{Methods}

\section{Subjects}

A total of 1,752 secondary school students, ranging from Form 1 to Form 4 participated in the survey. They were studying at the local aided or government schools but there was no swimming pool in their school campus. Students from the private and international secondary schools comprising a smaller proportion of all secondary students were not included in this study.

\section{Procedures}

Convenient sampling technique was utilized. The data were collected by filling out the questionnaires and each subject answered without interfering by others. Content validity was initially developed. The questionnaires were distributed, completed by students and were collected in the school morning assembly or recess by the researcher or the responsible teacher. Students commonly spent about 3 minutes to finish the questionnaire. The physical education teachers assisted to collect the questionnaires from the schools. Anonymous data were used throughout the entire survey. Two thousand questionnaires were disturbed out and the response rate was $87.6 \%$.

The questionnaire was divided into three parts. The first part contained the core questions related to the subject's background and perception about swimming, such as participation, interest, importance, sense of danger, etc. The second part involved questions about learning to swim, peer and parental influence, etc. The third part consisted of items related to family support. 


\section{Data Analysis}

'Able to swim' in this survey was operationally defined as an individual who was able to swim at least 50 meters in any form of swimming styles without any assistance. All collected data were input into Statistical Package for the Social Science (SPSS) for Window 18.0 version. The significant level (alpha level) was set at .05 in this study. Descriptive statistics for frequencies and percentages, Chi Square and independent t-test were employed for analysis.

\section{Results}

The main purpose of this survey was to investigate the swimming abilities of the secondary students in Hong Kong. Of the two thousand questionnaires distributed out, 248 cases were discarded due to incomplete data and 1,752 questionnaires (87.6\% of total data) were usable for analysis.

Table 1 showed the gender distribution of the present survey. $51.9 \% \quad(n=910)$ and $48.1 \% \quad(n=842)$ of the subjects were boys and girls, respectively (See Table 1).

Table 1. Frequency and Percentage of the Subjects' Gender.

\begin{tabular}{ccc}
\hline Gender & $\mathrm{n}$ & Percentage (\%) \\
\hline Boys & 910 & 51.9 \\
Girls & 842 & 48.1 \\
\hline
\end{tabular}

Table 2 showed the school levels of the subjects, ranging from studying in Form One to Form Four. 18.6\% $(n=326)$ of the subjects were Form 1, 35.6\% ( $n=624)$ of the subjects were Form 2, 22.4\% $(n=392)$ of the subjects were Form 3 and 23.4\% $(n=410)$ of the subjects were Form 4 (See Table 2).

Table 2. Frequency and Percentage of the Subjects' School Level.

\begin{tabular}{ccc}
\hline Grade & $\mathrm{n}$ & Percentage (\%) \\
\hline Secondary 1 & 326 & 18.6 \\
Secondary 2 & 624 & 35.6 \\
Secondary 3 & 392 & 22.4 \\
Secondary 4 & 410 & 23.4 \\
\hline
\end{tabular}

Table 3 presented the frequencies of the secondary students who were able to swim and unable to swim. It was found that $53.3 \% \quad(\mathrm{n}=933)$ of the subjects were acquiring swimming skill and able to swim whereas $46.7 \%(n=819)$ of the subjects who could not (see Table 3).

Table 3. Frequencies and Percentage of the Swimmers and Non-swimmers.

\begin{tabular}{ccc}
\hline Swimming skill & $\mathrm{n}$ & Percentage (\%) \\
\hline Able to swim & 933 & 53.3 \\
Unable to swim & 819 & 46.7 \\
\hline
\end{tabular}


Table 4 presented the gender difference between the boys and girls who were able and unable to swim.
Table 4. Frequencies and Percentages of the Subjects Able vs Unable to Swim with Gender.

\begin{tabular}{|l|l|l|l|l|}
\hline \multirow{2}{*}{ Gender } & \multicolumn{2}{|l|}{ Swimming Abilities } & \multirow{2}{*}{ Total } \\
\cline { 3 - 4 } & & Able to Swim & Unable to Swim & \\
\hline Boys & $\mathrm{n}$ & 551 & 359 & 910 \\
\hline & $\%$ within gender & 60.5 & 39.5 & $100 \%$ \\
\hline & $\%$ within swimming ability & 59.1 & 43.8 & $51.9 \%$ \\
\hline & $\%$ of total & 31.4 & 20.5 & $51.9 \%$ \\
\hline Girls & n & 382 & 460 & 842 \\
\hline & $\%$ within gender & 45.4 & 54.6 & $100 \%$ \\
\hline & $\%$ within swimming ability & 40.9 & 56.2 & $48.1 \%$ \\
\hline & $\%$ of total & 21.8 & 26.3 & $48.1 \%$ \\
\hline
\end{tabular}

Table 5 presented the frequencies of the secondary students who were able to swim and unable to swim among the school level. The survey revealed that 9.3\% ( $n=163)$ of F.1 students, $19.6 \% \quad(n=344)$ of F.2 students, 12.2\% ( $n=214)$ of F.3 students and 12.1\% ( $\mathrm{n}=212)$ of F.4 students were able to swim.

Table 5. Frequencies and Percentage of the Students Able vs Unable to Swim among School Level.

\begin{tabular}{|c|c|c|c|c|}
\hline \multirow{2}{*}{ Grade } & & \multicolumn{2}{|c|}{ Swimming abilities } & \multirow{2}{*}{ Total } \\
\cline { 3 - 4 } & & Able to swim & Unable to swim & \\
\hline F.1 & n & 163 & 163 & 326 \\
\hline & \% within grade of the subjects & 50 & 50 & $100 \%$ \\
\hline & \% within swimming ability & 17.5 & 19.9 & $18.6 \%$ \\
\hline & \% of total & 9.3 & 9.3 & $18.6 \%$ \\
\hline F.2 & n & 344 & 280 & 624 \\
\hline & \% within grade of the subjects & 55.1 & 44.9 & $100 \%$ \\
\hline & \% within swimming ability & 36.9 & 34.2 & $35.6 \%$ \\
\hline & \% of total & 19.6 & 16 & $35.6 \%$ \\
\hline F.3 & n & 214 & 178 & 392 \\
\hline & \% within grade of the subjects & 54.6 & 45.4 & $100 \%$ \\
\hline & \% within swimming ability & 22.9 & 21.7 & $22.4 \%$ \\
\hline F.4 & \% of total & 12.2 & 10.2 & $22.4 \%$ \\
\hline & n & 212 & 198 & 410 \\
\hline & \% within grade of the subjects & 51.7 & 48.3 & $100 \%$ \\
\hline & \% within swimming ability & 22.7 & 24.2 & $23.4 \%$ \\
\hline & \% of total & 12.1 & 11.3 & $23.4 \%$ \\
\hline
\end{tabular}


For the frequencies of the secondary students able to swim among the family economic status, 14.3\% ( $\mathrm{n}=178)$ of subjects whose family income was below $\$ 10,000$; $17.7 \% \quad(n=221)$ was between $\$ 10,001$ to $\$ 20,000 ; 8.9 \%$ $(n=111)$ was between $\$ 20,001$ to $\$ 30,000 ; 3.8 \% \quad(n=47)$ was between $\$ 30,001$ to $\$ 40,000 ; 2.6 \% \quad(n=33)$ was between $\$ 40,001$ to $\$ 50,000$ and $6.1 \%(n=76)$ of subjects who family income was more than $\$ 50,000$ were able to swim (see Table 6).

Table 6. Frequencies and Percentages of the Students Able vs Unable to Swim among Family Economic Status.

\begin{tabular}{|c|c|c|c|c|}
\hline \multirow[t]{2}{*}{ Family Income (HK\$) } & & \multicolumn{2}{|c|}{ Swimming abilities } & \multirow[t]{2}{*}{ Total } \\
\hline & & Able to swim & Unable to swim & \\
\hline \multirow{4}{*}{ Below 10,000} & $\mathrm{n}$ & 178 & 217 & 395 \\
\hline & $\%$ within economic status & 45.1 & 54.9 & $100 \%$ \\
\hline & $\%$ within swimming ability & 26.7 & 37.3 & $31.7 \%$ \\
\hline & $\%$ of total & 14.3 & 17.4 & $31.7 \%$ \\
\hline \multirow[t]{4}{*}{ Between $10,001-20,000$} & $\mathrm{n}$ & 221 & 225 & 446 \\
\hline & $\%$ within economic status & 49.6 & 50.4 & $100 \%$ \\
\hline & $\%$ within swimming ability & 33.2 & 38.7 & $35.8 \%$ \\
\hline & $\%$ of total & 17.7 & 18 & $35.8 \%$ \\
\hline \multirow[t]{4}{*}{ Between 20,001-30,000 } & $\mathrm{n}$ & 111 & 68 & 179 \\
\hline & $\%$ within economic status & 62 & 38 & $100 \%$ \\
\hline & $\%$ within swimming ability & 16.7 & 11.7 & $14.4 \%$ \\
\hline & $\%$ of total & 8.9 & 5.5 & $14.4 \%$ \\
\hline \multirow[t]{4}{*}{ Between $30,001-40,000$} & $\mathrm{n}$ & 47 & 21 & 68 \\
\hline & $\%$ within economic status & 69.1 & 30.9 & $100 \%$ \\
\hline & $\%$ within swimming ability & 7.1 & 3.6 & $5.5 \%$ \\
\hline & $\%$ of total & 3.8 & 1.7 & $5.5 \%$ \\
\hline \multirow[t]{4}{*}{ Between $40,001-50,000$} & $\mathrm{n}$ & 33 & 17 & 50 \\
\hline & $\%$ within economic status & 66 & 34 & $100 \%$ \\
\hline & $\%$ within swimming ability & 5 & 2.9 & $4 \%$ \\
\hline & $\%$ of total & 2.6 & 1.4 & $4 \%$ \\
\hline \multirow[t]{4}{*}{ More than 50,001} & $\mathrm{n}$ & 76 & 33 & 109 \\
\hline & $\%$ within economic status & 69.7 & 30.3 & $100 \%$ \\
\hline & $\%$ within swimming ability & 11.4 & 5.7 & $8.7 \%$ \\
\hline & $\%$ of total & 6.1 & 2.6 & $8.7 \%$ \\
\hline
\end{tabular}

Table 7 showed when the students learned to swim and Table 8 presented the method of learning to swim reported by the secondary school students.
Table 7. Time for the Students Acquiring Swimming Skill.

\begin{tabular}{lcc}
\hline Period & $\mathrm{n}$ & Percentage \\
\hline Kindergarten & 108 & 11.6 \\
Primary School & 716 & 76.6 \\
Secondary School & 111 & 11.9 \\
\hline
\end{tabular}


Table 8. Methods of Learning to Swim Reported by the Students.

\begin{tabular}{lll}
\hline Methods & $\mathrm{n}$ & Percentage $(\%)$ \\
\hline Public swimming class & 283 & 32.4 \\
Parents teaching & 214 & 24.5 \\
Self-learning & 206 & 23.6 \\
Private class & 98 & 11.2 \\
Swimming lessons from School PE & 53 & 6.0 \\
Others & 19 & 2.0 \\
\hline
\end{tabular}

For those students who were able to swim, they were further asked the reasons why they learned swimming. It was found that $44.3 \%$ of them acquired swimming skill due to the parental encouragement. $38.5 \%$ was due to self-interest and $8.3 \%$ was by reason of peer influence.

The questionnaire also consisted of questions about the reasons for unable to swim. $43.7 \%$ of those who could not swim replied that they were lack of skills to learn swimming. $38.8 \%$ found no time to learn swimming. $35.5 \%$ did not show interest in swimming. $31 \%$ indicated that swimming was a dangerous sport and $20.7 \%$ did not find any friends to accompany. $16.0 \%$ found difficulties in looking for swimming pools. $11.5 \%$ replied that swimming was useless.

When the subjects were asked about the school swimming class in physical education lesson, 54\% of the subjects replied that swimming class in PE lesson could not help to increase their interest in swimming and 55\% indicated that it could not develop swimming skills.

Interestingly, when looking at the economic background of the subjects, significant $(\chi 2=40.635, \mathrm{p}<$ $.05)$ difference was found in the frequencies between those students that were able and unable to swim. Apparently, students with better family income appeared that they were more likely having chances in learning to swim. In addition, more boys were able to swim as compared with the girls $(\chi 2=40.489, p<.05)$. No significant difference $(p>.05)$ in school levels was found between the swimmers and non-swimmers. Parental and peer support appeared to be important factors influencing the secondary school students learning to swim. Significant difference between the swimmers and nonswimmers was found in both factors: parental support $(\chi 2=880.459, p<.05)$ and peer support $(\chi 2=733.993, p<.05)$.

\section{Discussion}

The present finding revealed that only half of the secondary school students in Hong Kong were able to swim. According to the local Education Bureau, the School Physical Education is "education through the physical" and it aims to develop students' physical competence and knowledge of movement and safety, and their ability to use these to perform in a wide range of activities associated with the development of an active and healthy lifestyle. It also develops students' confidence and generic skills, especially those of collaboration, communication, creativity, critical thinking and aesthetic appreciation (Education Bureau, 2014). But unfortunately based on the present survey, nearly half of the secondary school students failed to participate in swimming as one of their active and healthy lifestyle. In fact, the current school PE 'key learn area (aquatic - swimming)' recommended that upon completion of primary 6 , students are able to swim 10 metres front crawl. It seemed that the school authority personnel should reveal the current swimming policy in Hong Kong schools.

In Australia, the swimming abilities of four thousand Queensland school children was studied and the median age for able to swim 10 metres was 6.5 years. Ninetyfive percent of children were able to swim by 11 years of age. Participation in formal swimming lessons was associated with an $88 \%$ reduction in the risk of drowning, as reported by Brenner et al. (2009). In the present survey, $76.6 \%$ of the subjects who were able to swim reported that they acquired swimming skills at primary school stage. Evidently, if swimming lessons are offered during primary schools, more children would be able to swim, but unfortunately due to constricted school curriculum as well as high academic pressure, many primary schools are unwilling to provide swimming lessons for their students. Twenty percent fewer children from lower socioeconomic levels were able to swim (Nixon, 
Pearn, \& Dugdale, 1979). The present finding tended to support this phenomenon that students with lower family income might have fewer chances to learn swimming. Taking swimming lessons after school might be a financial burden especially among those families demanding for social security assistance.

More boys were able to swim and possessed better swimming skills than girls in this study. Perhaps traditional Chinese culture could explain such occurrence as boys were generally physically active than girls. Thus, they are more likely to take part in various physical activities and play including swimming. It also appeared that young girls were reluctant to wear swimming suits during PE lessons as reported by some female PE teachers.

According to the Standards for Provision of Recreation Facilities by the Hong Kong Planning Department (2014), the standard of provision is one swimming pool complex per 287,000 population, i.e. $1 \mathrm{~m} 2$ water surface area per 85 persons. Due to limited urban space in Hong Kong, there was always a debate in the community demanding for more recreational and leisure pool. Such crowded pool environment might affect the intention of learning to swim among the young people.

Some suggested that swimming class could be offered during the extra-curricular periods. But it would create extra workload for the PE teachers and transportation between schools and the pools was also a safety concern. The present finding was in line with previous studies (Fredicks \& Eccles, 2005; Welk, 1999) in which they pointed out that parents was the most influencing factor for the youngsters' physical activity participation. In Hong Kong, the parents frequently arranged series of sedentary activities to their children during their spare time, such as learning piano and art work, and thus the children do not have sufficient time to participate in swimming.

The result also revealed that there was significant difference between the secondary school students who were able and unable to swim in their sense of interest, perception of danger and the importance toward swimming. Students who were able to swim tended to show more interest, feel safer and more important towards swimming than the non-swimmers. It might also explain that swimmers possessed higher level of confidence as well as greater self-efficacy to participate in swimming.
To conclude, the present survey was one of the few studies to be conducted in Hong Kong to evaluate the swimming abilities among the secondary school students. The finding provided the database for the school administrators and health care professionals to better understand the situations that nearly half of the current secondary school students were unable to swim. Should swimming be mandatory in school curriculum?

\section{References}

Batty, G. D., \& Lee, I. M., (2004). Physical activity and coronary heart disease. BMJ, 328, 1089-1090.

Brenner, R.A., Saluja, G, \& Smith, G.S. (2003). Swimming lessons, swimming ability, and the risk of drowning. Injury Control and Safety Promotion, 10(4), 211-6.

Brenner, R.A., Taneja, G.S., Haynie, D.L., Trumble, A.C., Qian, C., Klinger, R.M., \& Klebanoff, M.A. (2009). Association between swimming lessons and drowning in childhood: a case-control study. Arch Pediatr Adolesc Med. 163(3), 203-10.

Centres for Diseases Control and Prevention. (2014). http://www.cdc.gov/

Fredricks, J. A., Eccles, J. S. (2005). Family Socialization, Gender, and Sport Motivation and Involvement. Journal of Sport \& Exercise Psychology, 27(1),3-31.

Huang, S., Veiga, R., Sila, U., Reed, E., \& Hines, S. (1989). The effect of swimming in asthmatic childrenparticipants in a swimming program in the city of Baltimore. Journal of Asthma, 26(2), 117-121.

Hong Kong Planning Department. (2014). Hong Kong Special Administrative Region.

Leisure and Cultural Services Department. (2012). Hong Kong Special Administrative Region.

Nixon, J.W., Pearn, J.H., \& Dugdale, A.E. (1979). Swimming ability of children: a survey of 4000 Queensland children in a high drowning region. The Medical Journal of Australia, 2(5), 271-2. 
O'Flaherty, J.E., \& Pirie, P.L. (1997). Prevention of pediatric drowning and near-drowning: a survey of members of the American Academy of Pediatrics. Pediatrics. 99(2):169-74.

Onyekwelu, E. (2008). Critical Study Of Near Drowning Cases At A Pediatric Emergency Department In West Africa. The Internet Journal of Health, 8 (2).

Pang, O. H., \& Ha, S. C. (2008). Parental concerns in facilitating children's physical activity participation in Hong Kong. Journal of Physical Education and Recreation,14(1), 39-46.

Rosimini, C. (2003). Benefits of Swim Training for Children and Adolescents with Asthma. Journal of the American of Nurse Practitioners, 15(6), 247-252

Smith, A.L. (1999). Perceptions of peer relationship and physical activity participation in early adolescence. Journal of Sport \& Exercise Psychology, 21, 329-350

Smith, A. L. (2003). Peer relationships in physical activity contexts: a road less traveled in youth sport and exercise psychology research. Psychology of Sport and Exercise, 4, 25-39.
Wardell, C., \& Isbister, C. (2002). A swimming program for children with asthma. The Medical Journal of Australia, 4(18), 647-648.

Weiss, M. R., \& Duncan, S. C. (1992). The relationship between physical competence and peer acceptance in the context of children's sport participation. Journal of Sport and Exercise Psychology, 14, 177-191.

Welk, G. J. (1999). Promoting Physical Activity in Children: Parental Influence. Retrieved from Eric Digest.(ED436480).

\section{Correspondence}

Prof. Bik Chow

Department of Physical Education, Hong Kong Baptist University Kowloon Tong, Hong Kong.

Email: bchow@hkbu.edu.hk 